\title{
Influence of nitrate and ammonium availability on uptake kinetics of stream biofilms
}

Author(s): Miquel Ribot, Daniel von Schiller, Marc Peipoch, Francesc Sabater, Nancy B. Grimm and Eugènia Martí Source: Freshwater Science, 32(4):1155-1167. 2013.

Published By: The Society for Freshwater Science

DOI: http://dx.doi.org/10.1899/12-209.1

URL: http://www.bioone.org/doi/full/10.1899/12-209.1

BioOne (www.bioone.org) is a nonprofit, online aggregation of core research in the biological, ecological, and environmental sciences. BioOne provides a sustainable online platform for over 170 journals and books published by nonprofit societies, associations, museums, institutions, and presses.

Your use of this PDF, the BioOne Web site, and all posted and associated content indicates your acceptance of BioOne's Terms of Use, available at www.bioone.org/page/terms of use.

Usage of BioOne content is strictly limited to personal, educational, and non-commercial use. Commercial inquiries or rights and permissions requests should be directed to the individual publisher as copyright holder. 


\title{
Influence of nitrate and ammonium availability on uptake kinetics of stream biofilms
}

\author{
Miquel Ribot ${ }^{1,5}$, Daniel von Schiller ${ }^{2,6}$, Marc Peipoch ${ }^{1,7}$, Francesc Sabater ${ }^{3,8}$, \\ Nancy B. Grimm ${ }^{4,9}$, AND Eugènia Martí1,10 \\ ${ }^{1}$ Biogeodynamics and Biodiversity Group, Centre d'Estudis Avançats de Blanes, CSIC, Accés a la Cala St \\ Francesc 14, 17300, Blanes, Spain \\ ${ }^{2}$ Catalan Institute for Water Research, Emili Grahit 101, Edifici H2O, Parc Científic i Tecnològic de la \\ Universitat de Girona, 17003, Girona, Spain \\ ${ }^{3}$ Department of Ecology, Faculty of Biology, University of Barcelona, Avinguda Diagonal 645, \\ 08028 Barcelona, Spain \\ ${ }^{4}$ School of Life Sciences, Arizona State University, Tempe, Arizona 85287-4501 USA
}

\begin{abstract}
Human activity has significantly increased dissolved inorganic N (DIN) availability and has modified the relative proportion of $\mathrm{NO}_{3}{ }^{-}$and $\mathrm{NH}_{4}{ }^{+}$species in many streams. Understanding the relationship between DIN concentration and DIN uptake is crucial to predicting how streams will respond to increased DIN loading. Nonetheless, this relationship remains unclear because of the complex interactions governing DIN uptake. We aimed to evaluate how biofilms from 2 streams differing in background DIN concentration would respond to increases in availability and changes in speciation $\left(\mathrm{NO}_{3}{ }^{-}\right.$ or $\mathrm{NH}_{4}^{+}$) of DIN. We measured DIN uptake by biofilms in artificial flumes in each stream, using separate ${ }^{15} \mathrm{~N}_{-} \mathrm{NO}_{3}{ }^{-}$and ${ }^{15} \mathrm{~N}-\mathrm{NH}_{4}{ }^{+}$additions in a graded series of increasing DIN concentrations. The ambient uptake rate $(U)$ was higher for $\mathrm{NO}_{3}{ }^{-}$than for $\mathrm{NH}_{4}{ }^{+}$in both streams, but only $U$ for $\mathrm{NH}_{4}{ }^{+}$differed between streams. Uptake efficiency $\left(U_{N \text {-specific }}\right)$ at ambient conditions was higher in the low-N than in the high-N stream for both DIN species. A Michaelis-Menten model of uptake kinetics best fit the relationship between uptake and concentration in the case of $\mathrm{NH}_{4}{ }^{+}$(for both streams) but not in the case of $\mathrm{NO}_{3}{ }^{-}$ (neither stream). Moreover, saturation of $\mathrm{NH}_{4}{ }^{+}$uptake occurred at lower rates (lower $U_{\max }$ ) in the low-N than in the high-N stream, but affinity for $\mathrm{NH}_{4}{ }^{+}$was higher (lower $\mathrm{K}_{s}$ ) in the low-N stream. Together, these results indicate that the response capacity of biofilm communities to short-term increases of DIN concentration is determined primarily by the ambient DIN concentrations under which they develop. Our study also shows that DIN uptake by benthic biofilms varies with DIN availability and with DIN speciation, which often is modified by human activities.
\end{abstract}

Key words: nitrate, ammonium, biofilm, nitrogen uptake, Michaelis-Menten kinetics, stream, land use, agriculture.

Human activities have significantly increased the concentration of dissolved inorganic $\mathrm{N}$ (DIN) in streams (Howarth et al. 1996, Carpenter et al. 1998). Understanding how stream DIN uptake (i.e., the process by which stream biota immobilize DIN from the water column) responds to human alteration of

\footnotetext{
${ }^{5}$ E-mail addresses: mribot@ceab.csic.es

6 dvonschiller@icra.cat

7 mpeipoch@ceab.csic.es

8 fsabater@ub.edu

9 nbgrimm@asu.edu

10 eugenia@ceab.csic.es
}

DIN availability has become a research focus for stream ecologists (Mulholland and Webster 2010). Some researchers have studied DIN uptake kinetics (i.e., changes in uptake rates $[U]$ in response to changes in concentration) based on the relationship between whole-reach DIN uptake and DIN concentration by using measurements from different streams spanning a broad range of background DIN concentrations (Dodds et al. 2002, Bernot et al. 2006, Newbold et al. 2006, O'Brien et al. 2007). Other researchers have focused on DIN uptake kinetics within the same stream by following changes in whole-reach uptake in response to short-term DIN 
enrichment (Payn et al. 2005, Earl et al. 2006, Covino et al. 2010, O'Brien and Dodds 2010) or by investigating DIN uptake kinetics in mesocosms (Eppley et al. 1969, Kemp and Dodds 2002, O'Brien and Dodds 2008).

Three mathematical models describe the relationship between DIN uptake and concentration in streams. The first model corresponds to a $1^{\text {st }}$-order response in which uptake flux $\left(\mu \mathrm{g} \mathrm{N} \mathrm{m} \mathrm{N}^{-2} \mathrm{~s}^{-1}\right)$ is directly proportional to concentration of substrate (Dodds et al. 2002). The $2^{\text {nd }}$ model, the efficiency-loss model, follows a power relationship in which $U$ increases but efficiency declines with concentration (O'Brien et al. 2007). The $3^{\text {rd }}$ model follows MichaelisMenten kinetics and is characterized by saturation of uptake when availability exceeds biological demand (Earl et al. 2006). In general, results from interstream comparisons suggest that the linear and efficiencyloss models best fit the relationship between DIN uptake and concentration (Dodds et al. 2002, O'Brien et al. 2007). Conversely, results from enrichment experiments in the same stream or in mesocosms (i.e., with the same community) suggest that the Michaelis-Menten model best fits DIN uptake kinetics (Payn et al. 2005, Earl et al. 2006, Covino et al. 2010, O'Brien and Dodds 2010).

Human activities also change the relative proportions of the 2 major DIN species: $\mathrm{NO}_{3}{ }^{-}$and $\mathrm{NH}_{4}{ }^{+}$ (Stanley and Maxted 2008, Lassaletta et al. 2009, Martí et al. 2010). $U$ and kinetics are expected to differ between $\mathrm{NO}_{3}{ }^{-}$and $\mathrm{NH}_{4}{ }^{+}$because energetic costs of assimilation associated with $\mathrm{NO}_{3}{ }^{-}$are generally higher than those associated with $\mathrm{NH}_{4}{ }^{+}$(Dortch 1990, Naldi and Wheeler 2002). Furthermore, dissimilatory transformations, in which neither compound is incorporated into biomass, contribute to $\mathrm{NH}_{4}{ }^{+}$and $\mathrm{NO}_{3}{ }^{-}$uptake. Nitrification (i.e., oxidization of $\mathrm{NH}_{4}{ }^{+}$ to $\mathrm{NO}_{3}{ }^{-}$by autotrophic or heterotrophic Bacteria and Archaea) will result in apparent $\mathrm{NH}_{4}{ }^{+}$uptake, whereas apparent $\mathrm{NO}_{3}{ }^{-}$uptake may include denitrification (i.e., the respiratory process by which bacteria reduce $\mathrm{NO}_{3}{ }^{-}$to $\mathrm{N}_{2}$ ). These transformations are carried out by different organisms and governed by different controlling factors (Bothe et al. 2007), and thus, may contribute to the expected differences between $\mathrm{NO}_{3}{ }^{-}$and $\mathrm{NH}_{4}{ }^{+}$uptake kinetics. Most researchers have investigated $\mathrm{NO}_{3}{ }^{-}$or $\mathrm{NH}_{4}{ }^{+}$uptake separately. Thus, we do not know how uptake kinetics differ between these 2 DIN species under similar environmental conditions. In addition, little is known about differences in uptake kinetics of $\mathrm{NO}_{3}{ }^{-}$ or $\mathrm{NH}_{4}{ }^{+}$of stream biofilms (i.e., the microbial communities that develop on stream substrata) associated with increases in DIN availability. Understanding DIN uptake kinetics of stream biofilms is especially important because biofilms are major contributors to nutrient dynamics in stream networks (Pusch et al. 1998, Battin et al. 2003) and, therefore, may help ameliorate anthropogenic DIN inputs.

We compared $U$ and kinetics for $\mathrm{NO}_{3}{ }^{-}$and $\mathrm{NH}_{4}{ }^{+}$ between biofilms developed in 2 streams differing in background DIN concentrations. We measured biofilm $U$ in experiments in which we separately added ${ }^{15} \mathrm{~N}$-labeled $\mathrm{NO}_{3}{ }^{-}$and $\mathrm{NH}_{4}{ }^{+}$at increasing concentrations to artificial flumes in each stream. We predicted that ambient uptake flux would be higher for $\mathrm{NO}_{3}{ }^{-}$ than for $\mathrm{NH}_{4}^{+}$and in the high- $\mathrm{N}$ than in the low-N stream because of higher availability of $\mathrm{NO}_{3}{ }^{-}$with respect to $\mathrm{NH}_{4}{ }^{+}$and the overall higher DIN availability in the high-N stream. In terms of uptake kinetics, we predicted that the Michaelis-Menten model would best fit the relationship between DIN uptake and concentration because DIN uptake is mediated by enzymatic processes. In particular, we expected lower maximum uptake $\left(U_{\max }\right)$ and $1 / 2$-saturation constant $\left(K_{s}\right)$ for $\mathrm{NH}_{4}{ }^{+}$than for $\mathrm{NO}_{3}{ }^{-}$because of the lower energetic cost of assimilation of $\mathrm{NH}_{4}^{+}$than of $\mathrm{NO}_{3}{ }^{-}$. We further expected $U_{\max }$ and $K_{s}$ to be lower in the low-N stream than in the high-N stream because of differences in $\mathrm{N}$ affinity between stream biofilms resulting from different histories of nutrient exposure.

\section{Methods}

\section{Study sites}

Font del Regàs (lat $2^{\circ} 27^{\prime} 00^{\prime \prime} \mathrm{E}$, long $41^{\circ} 49^{\prime} 32^{\prime \prime} \mathrm{N}$; $929 \mathrm{~m}$ asl) is a forested stream situated within the protected area of the Parc Natural del Montseny at the headwaters of the catchment of the river La Tordera. Santa Coloma (lat $2^{\circ} 37^{\prime} 52^{\prime \prime} \mathrm{E}$, long $41^{\circ} 52^{\prime} 18^{\prime} \mathrm{N}$; $425 \mathrm{~m}$ asl) is an agricultural stream situated next to gardening plantations in a lower part of the same catchment. Discharge (mean \pm SE) was $56 \pm 12 \mathrm{~L} / \mathrm{s}$ for Font del Regàs and $163 \pm 35 \mathrm{~L} / \mathrm{s}$ for Santa Coloma (biweekly samplings from September 2004-July 2007; MR, DvS, FS, and EM, unpublished data). Concentrations of $\mathrm{NO}_{3}{ }^{-}$and $\mathrm{NH}_{4}{ }^{+}$were $181 \pm 11 \mu \mathrm{g} \mathrm{N} / \mathrm{L}$ and 12 $\pm 1 \mu \mathrm{g} \mathrm{N} / \mathrm{L}$ for Font del Regàs, and $780 \pm 44 \mu \mathrm{g}$ N/L and $19 \pm 2 \mu \mathrm{g} \mathrm{N} / \mathrm{L}$ for Santa Coloma (biweekly samplings from September 2004-July 2007; MR, DvS, FS, and EM, unpublished data). Hereafter, we refer to Font del Regàs as the low-N stream and to Santa Coloma as the high-N stream.

\section{Channel experiments}

We conducted experiments from 3 to 24 July 2007 in the low-N stream and from 23 October to 7 November 
2007 in the high-N stream. We placed a set of 6 parallel polyvinyl chloride (PVC) channels $(6 \mathrm{~m}$ long $\times 15 \mathrm{~cm}$ wide) on the stream bed in a metal structure that held them together and above the stream water (Fig. 1A). Water from an upstream tank fed all channels continuously with a mean $( \pm \mathrm{SE})$ flow rate of $1.8 \pm 0.018 \mathrm{~L} / \mathrm{min}$ (from measurements done daily throughout the experiments and in each channel). We filled the channels with stream cobbles of similar size and biofilm cover that were collected from the stream bed $<50 \mathrm{~m}$ upstream from the channel setting. We exposed channels to 5 sequential 24-h fertilization cycles each with an increased concentration $(1,4,8$, 16 , and $32 \times$ background concentration) of either $\mathrm{NO}_{3}{ }^{-}$or $\mathrm{NH}_{4}{ }^{+}$( $n=3$ channels each; Fig. $\left.1 \mathrm{~A}, \mathrm{~B}\right)$. We released solutions of $\mathrm{NO}_{3}{ }^{-}$(as $\mathrm{NaNO}_{3}$ ) or $\mathrm{NH}_{4}{ }^{+}$(as $\mathrm{NH}_{4} \mathrm{Cl}$ ) to the corresponding channels at a constant rate from a 3-output carboy (1/channel). We maintained a constant head in each carboy with a Masterflex (Vernon Hills, Illinois) L/S battery-powered peristaltic pump. We also added $\mathrm{PO}_{4}{ }^{3-}$ (as $\mathrm{NaH}_{2} \mathrm{PO}_{4} \cdot \mathrm{H}_{2} \mathrm{O}$ ) proportionally into the solution at each fertilization level to maintain the background stoichiometric ratio between DIN and soluble reactive $\mathrm{P}$ (SRP) throughout the fertilization cycles.

We conducted a tracer addition of either ${ }^{15} \mathrm{NO}_{3}{ }^{-}(n$ $=3$ channels $)$ or ${ }^{15} \mathrm{NH}_{4}{ }^{+}(n=3$ channels $)$ over the last $6 \mathrm{~h}$ of each fertilization level to estimate $U$ of biofilms. We added solutions amended with ${ }^{15} \mathrm{NO}_{3}{ }^{-}$(as 99\% enriched $\mathrm{K}^{15} \mathrm{NO}_{3}$ ) or ${ }^{15} \mathrm{NH}_{4}{ }^{+}$(as $99 \%$ enriched ${ }^{15} \mathrm{NH}_{4} \mathrm{Cl}$ ) and $\mathrm{NaCl}$ as a conservative tracer at a constant rate using a similar setup as described above. We calculated the amount of $\mathrm{K}^{15} \mathrm{NO}_{3}$ and ${ }^{15} \mathrm{NH}_{4} \mathrm{Cl}$ needed to produce a target $\delta^{15} \mathrm{~N}$ enrichment of 3000\% for both DIN species in the channels. To verify plateau conditions, we logged conductivity every $10 \mathrm{~s}$ at the end of each channel with a portable WTW conductivity meter (Weilheim, Germany).

Prior to fertilizations, we collected water at the downstream end of each channel for analysis of ambient nutrient concentrations (3 replicates/channel) and ${ }^{15} \mathrm{NH}_{4}{ }^{+}$and ${ }^{15} \mathrm{NO}_{3}{ }^{-}$signatures (1 replicate/ channel). We also collected composite biofilm samples for the analysis of biomass, pigment content, and natural abundance of ${ }^{15} \mathrm{~N}$ (1 replicate/channel) by scraping 3 randomly selected cobbles and filtering the biomass onto combusted, preweighed glass-fiber filters (GF/Fs; Whatman, Maidstone, UK). Before completing each fertilization period (when fertilization and ${ }^{15} \mathrm{~N}$ addition were running together), we collected another set of water and biofilm samples (3 replicates/channel) for analysis of nutrient concentration and ${ }^{15} \mathrm{NH}_{4}{ }^{+}$and ${ }^{15} \mathrm{NO}_{3}{ }^{-}$signatures. Then we stopped the additions, emptied the channels, cleaned
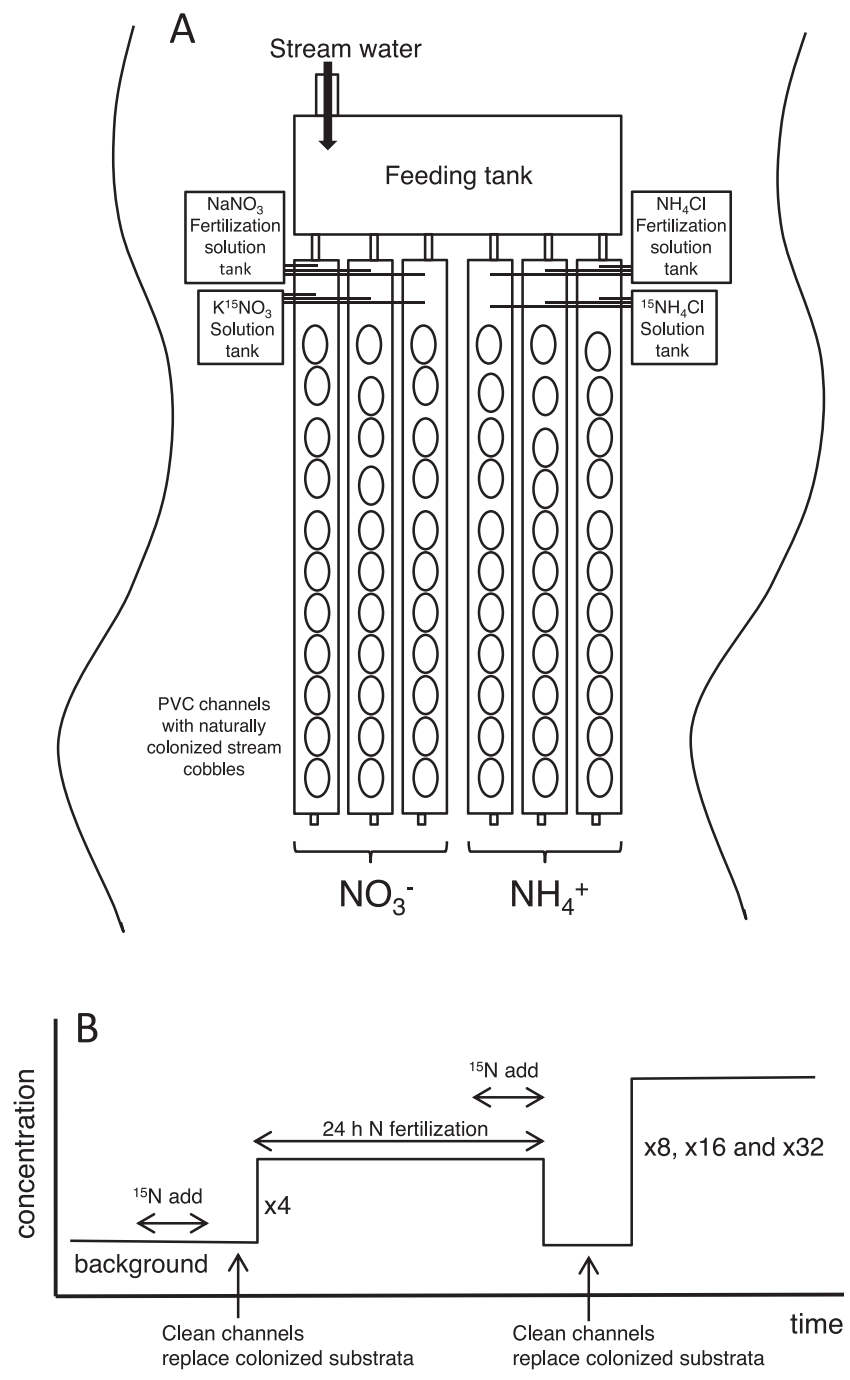

FIG. 1. Scheme of the channel setting used to experimentally approach the objectives of our study. A.- In-situ channel structure. Upstream water supplied the feeding tank, which in turn, fed each polyvinyl chloride (PVC) channel independently. Fertilization and ${ }^{15} \mathrm{~N}$ amended solutions for $\mathrm{NO}_{3}{ }^{-}$or $\mathrm{NH}_{4}{ }^{+}$reached each single channel independently ( 3 channels for each dissolved inorganic $\mathrm{N}$ [DIN] species). B.-Detail of experimental design to conduct the different fertilization levels (24 h each) and the ${ }^{15} \mathrm{~N}$ tracer additions (add; during the last $6 \mathrm{~h}$ of each fertilization treatment) to measure biofilm $\mathrm{N}$ uptake for each DIN species (3 channels for each DIN species treatment). For each $\mathrm{N}$ fertilization cycle, we used a new set of colonized substrata collected upstream of the channel setting.

them, and filled them again with cobbles from the stream to initiate the experiment with a higher fertilization level (Fig. 1B).

We filtered the water samples immediately through combusted GF/Fs into acid-washed, plastic containers and stored them on ice for transportation to the 
laboratory. We estimated the cobble surface area by covering it with $\mathrm{Al}$ foil and weighing the foil. We stored the filters with biofilm samples on ice in the field and froze (for chlorophyll $a$ analysis) or ovendried them (for ash-free dry mass [AFDM] and ${ }^{15} \mathrm{~N}$ analysis) in the laboratory until further processing. We logged photosynthetically active radiation (PAR) every 10 min with a SKP215 quantum sensor (Skye; Powys, UK) connected to a Campbell Scientific data logger (Logan, Utah). We measured temperature at plateau conditions with a WTW 340i portable conductivity meter.

\section{Laboratory analyses}

We analyzed water samples for concentrations of $\mathrm{NO}_{3}{ }^{-}, \mathrm{NH}_{4}{ }^{+}$, and SRP on a Bran+Luebbe (Norderstedt, Germany) TRAACS 2000 autoanalyzer with standard colorimetric methods (APHA 1995). We processed water samples for analysis of ${ }^{15} \mathrm{NO}_{3}{ }^{-}$and ${ }^{15} \mathrm{NH}_{4}{ }^{+}$with the $\mathrm{NH}_{3}$-diffusion technique (Sigman et al. 1997 and Holmes et al. 1998, respectively). To measure ${ }^{15} \mathrm{NO}_{3}{ }^{-}$, we amended a known volume of sample with $3 \mathrm{~g}$ of $\mathrm{MgO}$ and $5 \mathrm{~g}$ of $\mathrm{NaCl}$ and boiled it to remove the $\mathrm{NH}_{4}{ }^{+}$. We then added $0.5 \mathrm{mg} \mathrm{MgO}$ and $0.5 \mathrm{mg}$ Devarda's alloy to reduce the $\mathrm{NO}_{3}{ }^{-}$to $\mathrm{NH}_{4}{ }^{+}$, and treated the remaining sample as for ${ }^{15} \mathrm{NH}_{4}{ }^{+}$. To measure ${ }^{15} \mathrm{NH}_{4}{ }^{+}$, we amended a known volume of sample with $3 \mathrm{~g} / \mathrm{L}$ of $\mathrm{MgO}$ and $50 \mathrm{~g} / \mathrm{L}$ of $\mathrm{NaCl}$ and a Teflon filter packet containing a 1-cm-diameter combusted Whatman GF/D fiber glass filter acidified with $25 \mu \mathrm{L}$ of $2.5 \mathrm{M} \mathrm{KHSO}_{4}$ (to trap the volatilized $\mathrm{NH}_{3}$ ), and incubated it on a shaker at $40^{\circ} \mathrm{C}$ for $4 \mathrm{wk}$. Once the incubation was completed, we removed the filter packets and placed them in a desiccator for $4 \mathrm{~d}$. We encapsulated filters in tins and stored them until ${ }^{15} \mathrm{~N}$ analysis.

We oven-dried filters with biofilm samples at $60^{\circ} \mathrm{C}$ until they reached a constant mass. To estimate the biofilm AFDM $\left(\mathrm{g} / \mathrm{m}^{2}\right)$, we weighed subsamples on a Sartorious MC1 analytical balance (Göttingen, Germany) and combusted them at $500^{\circ} \mathrm{C}$ for $5 \mathrm{~h}$. We measured biofilm chlorophyll a content $\left(\mu \mathrm{g} / \mathrm{cm}^{2}\right)$ following McIntire et al. (1996). We submerged frozen filters in a known volume of $90 \%$ volume/volume acetone and kept them in the dark at $4{ }^{\circ} \mathrm{C}$ overnight. We sonicated the filters for $5 \mathrm{~min}$ and centrifuged them for $10 \mathrm{~min}$ at $4000 \mathrm{rpm}$. We measured the absorbance of the resultant supernatant at 664, 665, and $750 \mathrm{~nm}$ before and after acidification with a Shimadzu ultraviolet (UV) spectrometer (Tokyo, Japan). To determine the ${ }^{15} \mathrm{~N}$ signature of biofilms, we weighed $1-\mathrm{cm}$-diameter subsamples to the nearest $0.001 \mathrm{mg}$ on a Mettler-Toledo MX5 microbalance
(Greifensee, Switzerland) and encapsulated them in tins. We sent the samples for analysis at the University of California Stable Isotope Facility (Davis, California). We measured the $\mathrm{N}$ content (as \% dry mass) and the abundance of the heavier isotope, expressed as the ${ }^{14} \mathrm{~N}:{ }^{15} \mathrm{~N}$ ratio compared to that of a standard $\left(\mathrm{N}_{2}\right.$ from the atmosphere) using the notation of $\delta^{15} \mathrm{~N}$ in units of \%o, by continuous-flow isotoperatio mass spectrometry (20-20 mass spectrometer; PDZ Europa, Northwich, UK) after sample combustion in an online elemental analyzer (PDZ Europa ANCA-GSL).

\section{Calculation of $\mathrm{U}$ and data analysis}

We used independent $t$-tests to explore differences in ambient nutrient concentrations, biofilm AFDM, and biofilm chlorophyll $a$ content between streams.

To calculate the uptake rates of $\mathrm{NO}_{3}{ }^{-}$and $\mathrm{NH}_{4}{ }^{+}$, we first calculated the amount of ${ }^{15} \mathrm{~N}$ tracer contained in biofilm $\left({ }^{15} N_{\text {biofilm }} ; \mu \mathrm{g} \mathrm{N} / \mathrm{m}^{2}\right)$ with the equation:

$$
{ }^{15} N_{\text {biofilm }}=B_{\text {biofilm }} N\left(M F_{i}-M F_{b}\right) / 100
$$

where $B_{\text {biofilm }}$ is the biofilm biomass as dry mass per unit area, $\mathrm{N}$ is the biofilm $\mathrm{N}$ content expressed as \% dry mass, $M F$ is the molar fraction of ${ }^{15} \mathrm{~N}$ in biofilm at plateau conditions $\left(M F_{i}\right)$ and at background conditions $\left(M F_{b}\right)$.

We estimated the biofilm $U\left(\mu \mathrm{g} \mathrm{N} \mathrm{m}{ }^{-2} \mathrm{~s}^{-1}\right)$ for $\mathrm{NO}_{3}{ }^{-}$or $\mathrm{NH}_{4}{ }^{+}$with the equation (adapted from von Schiller et al. 2007):

$$
U=\frac{{ }^{15} N_{\text {bifilm }}}{T_{\text {addition }}\left({ }^{15} N_{\text {flux }} / N_{\text {flux }}\right)}
$$

where ${ }^{15} N_{\text {biofilm }}$ is the amount of ${ }^{15} \mathrm{~N}$ tracer in biofilm biomass from eq. 1, $T_{\text {addition }}$ is the duration of the ${ }^{15} \mathrm{~N}$ addition $(6 \mathrm{~h}),{ }^{15} \mathrm{~N}_{\text {flux }}$ is the ${ }^{15} \mathrm{~N}$ flux (as either $\mathrm{NO}_{3}{ }^{-}$or $\mathrm{NH}_{4}{ }^{+}$) at plateau conditions in the channel water, and $\mathrm{N}_{\text {flux }}$ is the total $\mathrm{N}$ flux $\left(\right.$ as $\mathrm{NO}_{3}{ }^{-}$or $\mathrm{NH}_{4}{ }^{+}$) at each fertilization level in the channel water based on concentration and channel flow rate $(\mu \mathrm{g} \mathrm{N} / \mathrm{s})$. We then calculated the biomass-specific $U\left(U_{N \text {-specifici }} \mathrm{d}^{-1}\right)$ for biofilm communities and DIN species as a surrogate of $\mathrm{N}$ uptake efficiency by dividing biofilm $U\left(\mu \mathrm{g} \mathrm{N} \mathrm{m}^{-2} \mathrm{~s}^{-1}\right)$ by the $\mathrm{N}$ content of dry mass $(\mu \mathrm{g} \mathrm{N} /$ $\left.\mathrm{m}^{2}\right)$.

To compare $U$ and $U_{N-\text { specific }}$ for $\mathrm{NO}_{3}{ }^{-}$and $\mathrm{NH}_{4}{ }^{+}$at ambient conditions within and between streams, we used a 2-way analysis of variance (ANOVA) with DIN species $\left(\mathrm{NO}_{3}{ }^{-}, \mathrm{NH}_{4}{ }^{+}\right)$and stream (low-N, high-N) as factors. We used post hoc Tukey Honestly Significant Difference tests after significant ANOVAs $(p<0.05)$ 
TABLE 1. Mean ( \pm SE) water temperature, photosynthetically active radiation (PAR), background nutrient concentration for both dissolved inorganic N (DIN) species, soluble reactive P (SRP), and biofilm ash-free dry mass (AFDM) and chlorophyll $a$ for both study streams during the experiments. Nutrient data from biweekly samplings from September 2004-July 2007 also provided (in parentheses).

\begin{tabular}{lcr}
\hline \hline \multicolumn{1}{c}{ Variable } & Low-N stream & High-N stream \\
\hline Water temperature $\left({ }^{\circ} \mathrm{C}\right)$ & $15.4 \pm 0.1$ & $11.0 \pm 0.2$ \\
PAR $\left(\mathrm{mol} \mathrm{m}^{-2} \mathrm{~d}^{-1}\right)$ & $9.5 \pm 3.4$ & $1.4 \pm 0.3$ \\
$\mathrm{NO}_{3}{ }^{+}(\mu \mathrm{g} \mathrm{N} / \mathrm{L})$ & $222 \pm 2(181 \pm 11)$ & $400 \pm 27(780 \pm 44)$ \\
$\mathrm{NH}_{4}{ }^{(\mu \mathrm{g} \mathrm{N} / \mathrm{L})}$ & $15 \pm 1(12 \pm 1)$ & $8 \pm 1(19 \pm 2)$ \\
$\mathrm{SRP}(\mu \mathrm{g} \mathrm{P} / \mathrm{L})$ & $11 \pm 0.3(4 \pm 0.5)$ & $3 \pm 0.3(15 \pm 2.6)$ \\
$\mathrm{DIN}: \mathrm{SRP}(\mathrm{molar})$ & $48 \pm 1(192 \pm 32)$ & $394 \pm 32(429 \pm 106)$ \\
AFDM $\left(\mathrm{g} / \mathrm{m}^{2}\right)$ & $0.9 \pm 0.1$ & $4.3 \pm 0.3$ \\
Chlorophyll $a\left(\mu \mathrm{g} / \mathrm{cm}^{2}\right)$ & $0.3 \pm 0.03$ & $2.6 \pm 0.2$ \\
\hline
\end{tabular}

to further examine the effects of stream and DIN species on $U$ and $U_{N \text {-specific }}$.

To explore the relationship between $U$ and concentration of each DIN species at the different levels of fertilization, we determined the fit of our experimental data to the 3 mathematical models described in the introduction. The $1^{\text {st }}$-order response model followed the equation:

$$
U=a+b C
$$

where $U$ is assumed to increase linearly with DIN concentration $(C)$ and $a$ and $b$ are a constant and the slope, respectively. The Michaelis-Menten model followed the equation:

$$
U=\frac{U_{\max } C}{K_{s}+C}
$$

where $C$ is the DIN concentration, $U_{\max }$ is the maximum $U$, and $K_{S}$ is the concentration at which $1 / 2$ $U_{\max }$ is reached. $K_{s}$ is an indicator of the biofilm affinity for DIN. High values indicate lower affinity than low values. The efficiency-loss model followed the equation:

$$
U=a C^{b}
$$

where $U$ is assumed to increase with DIN concentration $(C)$ as a power law with exponent $b<1$.

The parameters $a$ and $b$ from each mathematical model (for the Michaelis-Menten model, $U_{\max }$ corresponds to $a$ and $K_{s}$ corresponds to $b$ ), were calculated based on the Gauss-Newton algorithm, an iterative process that seeks the values of the parameters that minimize the sum of the squared differences between the observed and predicted values of the dependent variable. We estimated the confidence intervals (CIs; 95\%) for each coefficient by the generic function confint powered by $\mathrm{R}$ software (version 2.14.0; $\mathrm{R}$
Development Core Team, Vienna, Austria). The default method assumes asymptotic normality, and requires that suitable coef and vcov methods be available. The default method can be called directly for comparison with other methods. We used the Akaike Information Criterion (AIC) to estimate Akaike weights $\left(w_{i}\right)$, which yield the relative likelihood of each model given a particular data set. Within the set of candidate models for the data, we selected the model with the highest $w_{i}$.

We conducted all statistical tests with $\mathrm{R}$. When necessary, data were $\log (x)$-transformed before analysis to meet assumptions of homogeneity of variance and normality (Zar 1996).

\section{Results}

Environmental conditions differed substantially between the 2 study streams during the experiments (Table 1). Mean water temperature and PAR were 1.4 and $7 \times$ higher, respectively, in the low-N stream than in the high- $\mathrm{N}$ stream. Consistent with the long-term trend (i.e., biweekly sampling), mean $\mathrm{NO}_{3}{ }^{-}$concentration was $2 \times$ higher in the high- $\mathrm{N}$ than in the low- $\mathrm{N}$ stream ( $t$-test, $p<0.001$; Table 1$)$. In contrast to the long-term trend, mean $\mathrm{NH}_{4}{ }^{+}$concentration was $2 \times$ higher in the low-N stream than in the high-N stream ( $t$-test, $p<0.001$; Table 1). Mean SRP concentration was $4 \times$ lower and mean DIN:SRP ratio was $8 \times$ higher in the high- $\mathrm{N}$ than in the low-N stream ( $t$-test, $p<$ 0.001). Mean biofilm AFDM and chlorophyll $a$ content were higher ( 5 and $9 \times$, respectively) in the high- $\mathrm{N}$ than in low-N stream $(t$-test, $p<0.001)$.

DIN species, stream, and the DIN $\times$ stream interaction affected both $U$ and $U_{N \text {-specific }}$ at ambient concentrations (ANOVA, all $p<0.01)$. $U_{\mathrm{NO}_{3}-}(3.1 \pm$ $0.6 \mu \mathrm{g} \mathrm{N} \mathrm{m}^{-2} \mathrm{~s}^{-1}$ in the low-N stream, $4.1 \pm 0.8 \mu \mathrm{g} \mathrm{N}$ $\mathrm{m}^{-2} \mathrm{~s}^{-1}$ in the high-N stream) was higher than $U_{\mathrm{NH} 4+}$ $\left(0.3 \pm 0.02 \mu \mathrm{g} \mathrm{N} \mathrm{m}^{-2} \mathrm{~s}^{-1}\right.$ in the low-N stream, $0.06 \pm$ $0.01 \mu \mathrm{g} \mathrm{N} \mathrm{m} \mathrm{m}^{-2} \mathrm{~s}^{-1}$ in the high-N stream) in both 

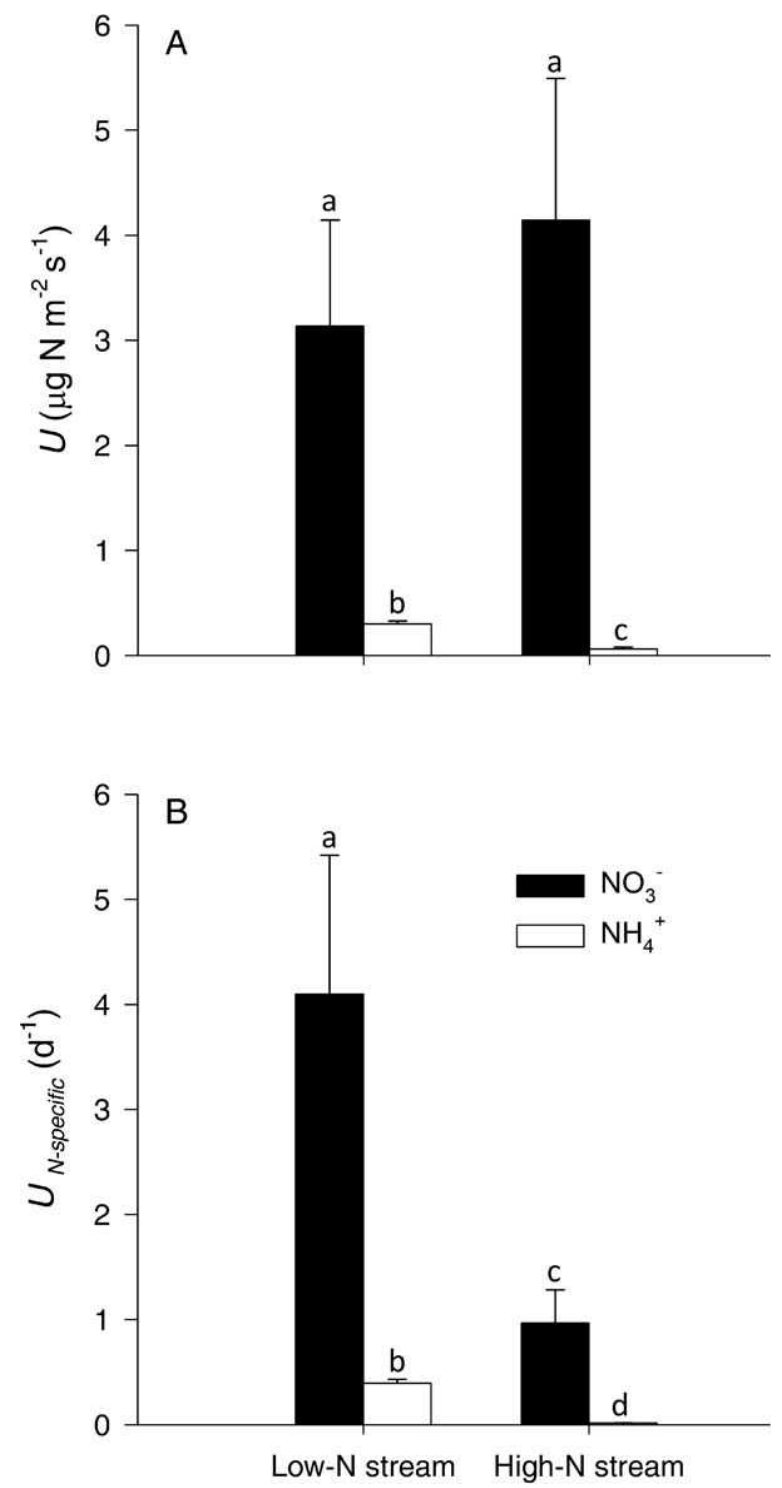

FIG. 2. Mean $( \pm 1 \mathrm{SE} ; n=3)$ uptake rate $(U)(\mathrm{A})$ and biomass-specific $\mathrm{N}$ uptake rate $\left(U_{N \text {-specific }}\right)$ (B) at ambient concentrations for the 2 dissolved inorganic $\mathrm{N}$ species $\left(\mathrm{NO}_{3}{ }^{-}\right.$and $\left.\mathrm{NH}_{4}{ }^{+}\right)$and study streams. Bars with the same letters are not significantly different $(p>0.05)$ based on post hoc Tukey Honestly Significant Difference test.

streams (Fig. 2A). $U_{\mathrm{NH} 4+}$ differed between streams (Tukey HSD test, $p=0.001$ ), whereas $U_{\mathrm{NO} 3}-$ did not (Tukey HSD test, $p=0.636)$. $U_{N \text {-specific }}$ for $\mathrm{NO}_{3}{ }^{-}(4.1 \pm$ $0.8 \mathrm{~d}^{-1}$ in the low-N stream, $1.0 \pm 0.2 \mathrm{~d}^{-1}$ in the high$\mathrm{N}$ stream) was higher than $U_{N \text {-specific }}$ for $\mathrm{NH}_{4}{ }^{+}(0.4 \pm$ 0.02 in the low-N stream, $0.01 \pm 0.002$ in the high-N stream) in both streams (Fig. 2B). In contrast to $U$, $U_{N \text {-specific }}$ for both $\mathrm{NO}_{3}{ }^{-}$and $\mathrm{NH}_{4}{ }^{+}$differed between streams (Tukey HSD test, $p<0.001$ ).

Uptake responses to increases in DIN concentration differed substantially between DIN species and streams (Fig. 3A-D). The relationship between $U$ and $\mathrm{NO}_{3}{ }^{-}$concentration differed between streams, but uptake kinetics did not fit Michaelis-Menten model in either stream (Fig. 3A, B). In the low-N stream, AIC analysis indicated that the relationship between $U$ and $\mathrm{NO}_{3}{ }^{-}$concentration better fit a $1^{\text {st }}$ order model with a negative slope (Table 2). Conversely, in the high $\mathrm{N}$-stream, 95\% CIs for $b$ in all 3 models contained 0 , indicating no significant fit, and AIC analysis resulted in no clear model selection (Table 2).

$U$ for $\mathrm{NH}_{4}{ }^{+}$varied with increases in $\mathrm{NH}_{4}{ }^{+}$concentrations (Fig. 3C, D). The AIC analysis indicated the Michaelis-Menten model as the best fit for the relationship between $U$ and $\mathrm{NH}_{4}{ }^{+}$concentration in both streams (Table 2). However, uptake kinetic parameters differed between streams. $U_{\max }$ and $K_{s}$ were lower in the low- $\mathrm{N}$ than in the high-N stream, and $95 \%$ CIs did not overlap (Table 2).

\section{Discussion}

We evaluated the response of biofilm $U$ to changes in DIN concentration, and tested whether this response varied among DIN species. We used an experimental approach that combined nutrient fertilizations and ${ }^{15} \mathrm{~N}$-tracer additions in situ in artificial flumes. We predicted that $U$ and uptake kinetics would depend on DIN species $\left(\mathrm{NO}_{3}{ }^{-}\right.$vs $\left.\mathrm{NH}_{4}{ }^{+}\right)$and ambient DIN concentration in the stream (low-N vs high-N). Our results supported these predictions only partially. $U$ was higher for $\mathrm{NO}_{3}{ }^{-}$than for $\mathrm{NH}_{4}{ }^{+}$in both streams, but only $U_{\mathrm{NH} 4+}$ differed between streams, with lower values in the high-N stream. In addition, $U_{N \text {-specific }}$ at ambient conditions was higher in the low-N stream for both DIN species. In terms of uptake kinetics, the Michaelis-Menten model best fit the relationship between $U$ and concentration in the case of $\mathrm{NH}_{4}{ }^{+}$(for both streams), but not in the case of $\mathrm{NO}_{3}{ }^{-}$(neither stream). Moreover, saturation of $\mathrm{NH}_{4}{ }^{+}$ uptake occurred at lower $U_{\max }$ in the low-N stream than in the high- $\mathrm{N}$ stream, but affinity for $\mathrm{NH}_{4}{ }^{+}$was higher (lower $K_{s}$ ) in the low-N stream.

\section{Biofilm DIN uptake in streams of contrasting DIN availability and speciation}

$U$ of epilithic biofilm for both DIN species under ambient conditions in our study were similar to values reported from previous studies using wholestream ${ }^{15} \mathrm{~N}$-tracer additions (Mulholland et al. 2000, Tank et al. 2000, Hamilton et al. 2001, Merriam et al. 2002, Ashkenas et al. 2004, von Schiller et al. 2009, Sobota et al. 2012). This result indicates that values of 

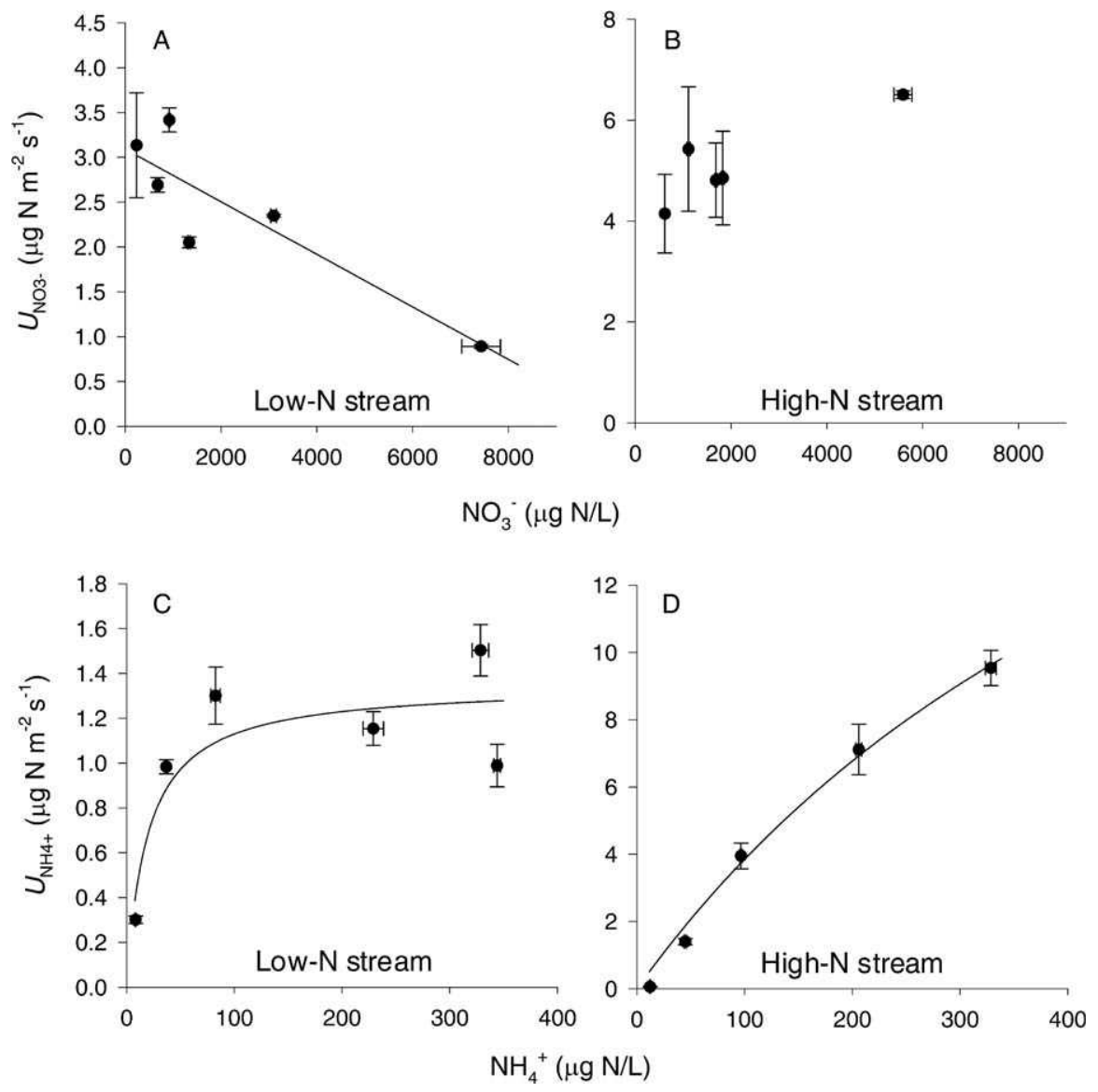

FIG. 3. Mean $( \pm 1 \mathrm{SE} ; n=3)$ uptake rates $(U)$ for $\mathrm{NO}_{3}{ }^{-}\left(U_{\mathrm{NO} 3-}\right)(\mathrm{A}, \mathrm{B})$ and $\mathrm{NH}_{4}{ }^{+}\left(U_{\mathrm{NH} 4+}\right)(\mathrm{C}, \mathrm{D})$ in the low-N $(\mathrm{A}, \mathrm{C})$ and high-N $(\mathrm{B}, \mathrm{D})$ streams. The first point in each panel corresponds to $U$ measured at ambient concentration. Lines represent the selected regression model from Akaike Information Criterion analysis (see Table 2 for regression statistics).

$U$ in our channel experiments were representative of natural field conditions.

Ambient $U_{\mathrm{NO} 3-}$ was $10 \times$ higher than $U_{\mathrm{NH} 4+}$ in both streams, even though $\mathrm{NH}_{4}^{+}$is theoretically an energetically less costly DIN source and, thus, was expected to be preferentially assimilated over $\mathrm{NO}_{3}{ }^{-}$ (Dortch 1990, Naldi and Wheeler 2002). Estimated values of the relative preference index (RPI) were $\sim 1$ in the 2 streams. This index was proposed by Dortch (1990) as a means to determine the preference for $\mathrm{NH}_{4}{ }^{+}$over $\mathrm{NO}_{3}{ }^{-}$(values $<1$ ) or for $\mathrm{NO}_{3}{ }^{-}$over $\mathrm{NH}_{4}{ }^{+}$ (values $>1$ ). The RPI value of $\sim 1$ in our study suggests that biofilms in the 2 streams have no preference for either DIN species. Thus, the observed higher $U_{\mathrm{NO} 3-}$ than $U_{\mathrm{NH} 4+}$ was mostly attributable to the higher concentrations of $\mathrm{NO}_{3}{ }^{-}$than of $\mathrm{NH}_{4}{ }^{+}$.

Ambient $U_{\mathrm{NO} 3-}$ did not differ between streams, but $U_{\mathrm{NH} 4+}$ was $10 \times$ lower in the high-N than in the low-N stream. Higher $\mathrm{NO}_{3}{ }^{-}$availability relative to $\mathrm{NH}_{4}{ }^{+}$ availability in the high- $\mathrm{N}$ stream may have favored uptake of $\mathrm{NO}_{3}{ }^{-}$over $\mathrm{NH}_{4}{ }^{+}$in the high-N stream, as suggested by other authors (Fellows et al. 2006, Newbold et al. 2006, Bunch and Bernot 2012). Furthermore, at low $\mathrm{NH}_{4}{ }^{+}$concentration, the presence of $\mathrm{NO}_{3}{ }^{-}$can favor $\mathrm{NO}_{3}{ }^{-}$assimilation (Geisseler et al. 2010). Expression and biosynthesis of assimilatory nitrate reductase (the enzyme responsible for $\mathrm{NO}_{3}{ }^{-}$ assimilation processes) is induced by $\mathrm{NO}_{3}{ }^{-}$and $\mathrm{NO}_{2}{ }^{-}$ and suppressed by $\mathrm{NH}_{4}{ }^{+}$(Gonzalez et al. 2006). Thus, the concurrence of high $\mathrm{NO}_{3}{ }^{-}$and low $\mathrm{NH}_{4}{ }^{+}$ concentration at ambient conditions in the high- $\mathrm{N}$ stream may have led to lower $\mathrm{NH}_{4}{ }^{+}$assimilation rates than in the low-N stream.

Differences in nitrification, which can contribute to $\mathrm{NH}_{4}{ }^{+}$uptake in biofilms, are another potential explanation for the differences in $U$ between streams. If nitrification rate were constrained by the low substrate $\left(\mathrm{NH}_{4}^{+}\right)$availability in the high-N stream, then we would expect the contribution of nitrification to total $\mathrm{NH}_{4}{ }^{+}$uptake to be lower in that stream. In both streams, $\delta^{15} \mathrm{NO}_{3}{ }^{-}$increased during plateau conditions in the channels where we did ${ }^{15} \mathrm{NH}_{4}{ }^{+}$ 
additions, a result indicative of nitrification (2.6 \pm $0.5 \%$ and $1.9 \pm 0.9 \%$ in the low- $\mathrm{N}$ and the high-N streams, respectively). Based on these $\delta^{15} \mathrm{NO}_{3}$ increases, we estimated the contribution of nitrification to total biofilm $\mathrm{NH}_{4}{ }^{+}$uptake for each fertilization cycle. This contribution ranged from 0.2 to $7.6 \%$ in the low$\mathrm{N}$ stream, whereas it was $<0.2 \%$ in the high-N stream. These results contrast with findings from Bernhardt et al. (2002), who found a higher contribution of nitrification to total $\mathrm{NH}_{4}{ }^{+}$uptake in high- $\mathrm{NO}_{3}{ }^{-}$ streams of Hubbard Brook (New Hampshire, USA). They hypothesized that when assimilatory processes switch to $\mathrm{NO}_{3}{ }^{-}$uptake (i.e., in high- $\mathrm{NO}_{3}{ }^{-}$streams), competition between nitrifiers and heterotrophs is ameliorated, resulting in higher nitrification rates. Our data do not support this mechanism because nitrification rate was probably lower in the high-N than in the low-N stream. Instead, we suggest that combination of lower $\mathrm{NH}_{4}^{+}$assimilation and lower nitrification by biofilms in the high-N stream explains the differences in $U_{\mathrm{NH} 4+}$ between streams.

$U_{N-s p e c i f i c}$ values indicate that the biofilm from the high-N stream took up both $\mathrm{NO}_{3}{ }^{-}$and $\mathrm{NH}_{4}{ }^{+}$from the water column less efficiently than the biofilm from the low-N stream. Lower uptake efficiencies often occur in streams with high DIN concentrations because of saturation of assimilative processes ( $\mathrm{O}^{\prime}$ Brien et al. 2007). Thus, our results suggest functional differences in the way DIN is cycled within biofilm communities grown under low- and high-N conditions, which in turn, may lead to differences in the uptake kinetics for both DIN species between stream types.

\section{Biofilm DIN uptake kinetics}

Contrary to expectations from nutrient kinetic theory, increases in $\mathrm{NO}_{3}{ }^{-}$availability did not enhance biofilm $U_{\mathrm{NO} 3-}$. In the high-N stream, addition of $\mathrm{NO}_{3}{ }^{-}$had no effect on biofilm $U$, suggesting that uptake capacity of biofilm assemblages probably was saturated at the ambient $\mathrm{NO}_{3}{ }^{-}$concentration. Earl et al. (2006) suggested that when $\mathrm{N}$ is not limiting in streams, a 0-order mathematical model (i.e., constant rate with slope $=0$ ) is more applicable than a higherorder model, a suggestion in concordance with our results in the high N-stream. Alternatively, the lack of biofilm uptake response to increases in $\mathrm{NO}_{3}{ }^{-}$concentration might be explained by tight coupling of $\mathrm{NO}_{3}{ }^{-}$uptake to availability of other nutrients (Fairchild et al. 1985, Sterner et al. 1992). Schanz and Juon (1983) suggested that $\mathrm{P}$ is a potentially limiting element at DIN:P $>20$ (others have suggested a transition from $\mathrm{N}$ to $\mathrm{P}$ limitation at DIN:P $\approx 16-17$; Redfield 1958, Grimm and Fisher 1986). We added 
SRP in the fertilization solutions to maintain background DIN:P, but ratios were well above the potential P-limitation thresholds, especially in the high-N stream $(394 \pm 32 \mu \mathrm{g} \mathrm{P} / \mathrm{L})$. In this sense, $\mathrm{NO}_{3}{ }^{-}$ uptake in the high-N stream may have been constrained by $\mathrm{P}$ insufficiency. However, if $\mathrm{P}$ were the limiting nutrient, then increases in $\mathrm{P}$ availability should alleviate $\mathrm{P}$ limitation and, thus, enhance $\mathrm{NO}_{3}{ }^{-}$uptake. We think this alternative explanation is unlikely because previous nutrient-limitation bioassays in the high- $\mathrm{N}$ stream failed to show $\mathrm{P}$ limitation (von Schiller et al. 2007).

Increases in $\mathrm{NO}_{3}{ }^{-}$availability in the low-N stream produced a decrease in biofilm $U$, indicating a possible inhibitory effect of high $\mathrm{NO}_{3}{ }^{-}$concentrations on biofilm uptake in this stream. Inhibitory effects on the uptake of $\mathrm{NH}_{4}{ }^{+}$or $\mathrm{NO}_{2}{ }^{-}$at high concentrations have been reported in the literature (usually associated with nitrification processes; Kim et al. 2006, Vadivelu et al. 2007). However, as far as we know, no previous evidence exists for inhibition of $\mathrm{NO}_{3}{ }^{-}$ uptake at high $\mathrm{NO}_{3}{ }^{-}$concentrations. However, inhibitory effects of long-term $\mathrm{NO}_{3}{ }^{-}$enrichment have been reported for periphyton growth in nutrientdiffusing substrate experiments (Bernhardt and Likens 2004), and a few investigators have shown potentially toxic effects of $\mathrm{NO}_{3}{ }^{-}$on freshwater animals and plants (Camargo and Alonso 2006, Lambert and Davy 2011). Our experiments do not allow us to identify the mechanisms underlying observed patterns but do provide evidence that a short-term, sharp increase in $\mathrm{NO}_{3}{ }^{-}$concentration may be inhibitory.

Michaelis-Menten kinetics described biofilm uptake responses to increases in $\mathrm{NH}_{4}{ }^{+}$concentration in both streams. Values of $K_{s}$ were higher than ambient concentrations of $\mathrm{NH}_{4}{ }^{+}$in both streams, so we conclude that biofilm uptake for this DIN source was below saturation at ambient concentrations (Tilman 1982). Therefore, biofilms were able to respond positively to short-term increases in $\mathrm{NH}_{4}{ }^{+}$concentration within a certain range in the 2 streams. Bunch and Bernot (2012) also compared uptake responses of microbial communities to $\mathrm{NH}_{4}{ }^{+}$and $\mathrm{NO}_{3}{ }^{-}$enrichments. They observed that responses to $\mathrm{NH}_{4}{ }^{+}$were immediate and pronounced, whereas responses to $\mathrm{NO}_{3}{ }^{-}$were delayed and more variable. They suggested that preference for $\mathrm{NH}_{4}{ }^{+}$as a DIN source by microbial communities dictates stronger and more rapid uptake responses to changes in $\mathrm{NH}_{4}{ }^{+}$than in $\mathrm{NO}_{3}{ }^{-}$concentration.

Our results agree with those by Bunch and Bernot (2012) in showing rapid response to increases in $\mathrm{NH}_{4}{ }^{+}$. However, the values of RPI of $\sim 1$ in our study indicated no clear preference for $\mathrm{NH}_{4}{ }^{+}$over $\mathrm{NO}_{3}{ }^{-}$, at least under ambient conditions. An alternative explanation for the difference in the kinetic responses between $\mathrm{NO}_{3}{ }^{-}$and $\mathrm{NH}_{4}{ }^{+}$involves enzymatic responses to short-term changes in availability. Increased availability of $\mathrm{NH}_{4}^{+}$in $\mathrm{NH}_{4}{ }^{+}$-amended channels may have triggered repression of $\mathrm{NO}_{3}{ }^{-}$ reductase and increased biofilm $\mathrm{NH}_{4}{ }^{+}$uptake to meet $\mathrm{N}$ demand (Gonzalez et al. 2006). This mechanism could explain the positive biofilm $\mathrm{NH}_{4}{ }^{+}$uptake response to increases in $\mathrm{NH}_{4}{ }^{+}$concentration even though uptake responses for $\mathrm{NO}_{3}{ }^{-}$indicated that biofilm demand for this DIN species was saturated at ambient conditions. Previous investigators have found a Michaelis-Menten response of nitrification rates to increases in $\mathrm{NH}_{4}{ }^{+}$concentration within a range of $\mathrm{NH}_{4}{ }^{+}$concentrations similar to that used in our study (Koper et al. 2010). Nitrification probably was substrate-limited at the relatively low $\mathrm{NH}_{4}{ }^{+}$ concentrations in the 2 study streams, which would produce a positive response to increased $\mathrm{NH}_{4}^{+}$ concentration that conforms to a Michaelis-Menten model. However, our a posteriori calculations of nitrification contribution to the whole-channel uptake suggest that nitrification is only a minor contributor to observed kinetics of $\mathrm{NH}_{4}^{+}$uptake. We suggest that a combination of several mechanisms best explains the different kinetic responses of $\mathrm{NH}_{4}{ }^{+}$and $\mathrm{NO}_{3}{ }^{-}$in the study streams.

$\mathrm{NH}_{4}{ }^{+}$uptake kinetics fit the Michaelis-Menten model in the 2 streams, but the kinetic parameters $\left(K_{s}\right.$ and $\left.U_{\max }\right)$ clearly differed between streams, supporting our predictions. $\mathrm{NH}_{4}{ }^{+} U_{\text {max }}$ of the biofilm in the high-N stream was $21 \times$ higher than $U_{\max }$ of the biofilm in the low-N stream. The high-N stream had higher biofilm biomass and more photoautotrophic organisms (as indicated by chlorophyll $a$ content) than the low-N stream, a result that could explain the higher $U_{\max }$ observed in the high-N stream. However, $U_{\max }$ weighted by $\mathrm{N}$ content of biofilm dry mass, a surrogate measure of uptake efficiency, was only $4 \times$ higher in the high-N stream. Therefore, biofilms were relatively more efficient in $\mathrm{NH}_{4}{ }^{+}$uptake in the low-N than in the high-N stream, a result that is in agreement with uptake results measured at ambient DIN conditions.

In contrast, biofilms showed a higher affinity (lower $K_{s}$ ) for $\mathrm{NH}_{4}{ }^{+}$in the low-N stream than in the high $\mathrm{N}$ stream. Higher affinities for substrate often are attributed to exposure of microorganisms to lower ambient concentrations (Collos et al. 2005, MartensHabbena et al. 2009). This explanation may not apply to our study if we consider only ambient $\mathrm{NH}_{4}{ }^{+}$ concentration, which was similar and low in the 2 
streams. However, when discussing nutrient limitation, it is more appropriate to consider total DIN concentration, which was $2 \times$ lower in the low- $\mathrm{N}$ than in the high-N stream, because biofilms can meet their $\mathrm{N}$ demand by uptake of either DIN species. Alternatively, differences in $\mathrm{NH}_{4}{ }^{+}$affinity between streams could be caused by boundary-layer constraints arising from differences in biofilm structure (Dodds et al. 2002). In support of this idea, the higher AFDM content per unit area in the high-N stream implies thicker biofilms and limitation of diffusion of DIN to all cells in the biofilm (Stewart 2003, Teissier et al. 2007). Limitation by diffusion has been demonstrated for uptake of inorganic $\mathrm{C}$ and nitrification activity in model biofilms, with both processes restricted to the surface layer of the biofilm (Gieseke et al. 2005). As a result, the thickness of the biofilm in the high-N stream may contribute to an increase in the range of $\mathrm{NH}_{4}^{+}$concentrations within which $U_{\mathrm{NH} 4+}$ responds positively. Constraints resulting from diffusion limitation in thicker biofilms operate for both $\mathrm{N}$ assimilation and nitrification and, thus, can amplify the range of $\mathrm{NH}_{4}{ }^{+}$concentrations that can be reached before saturation occurs because the 2 processes may have different kinetics.

We cannot rule out differences in environmental conditions, such as light availability and temperature, between the 2 streams as potential causes of differences in biofilm uptake kinetics for $\mathrm{NH}_{4}{ }^{+}$. We tried to conduct experiments in streams with similar environmental conditions, but a large flood in the high-N stream forced us to postpone the experiment until the biofilm communities recovered fully. As a result, temperature and light availability were higher in the low- $\mathrm{N}$ than in the high-N stream during the experiments and could have enhanced biofilm activity and kinetic responses in the low-N stream. However, the effect of temperature on nutrient uptake kinetics is unclear, and Smith (2011) found no evidence of sensitivity of Michaelis-Menten parameters to temperature. Light availability was higher in the low-N stream, but biofilm chlorophyll a content was $9 \times$ higher in the high-N than in the low-N stream. Thus, this factor could not have caused the observed kinetic differences, at least for the photoautotrophic component of the biofilms. Thus, observed differences in biofilm uptake kinetics between streams seem to be more influenced by differences in DIN concentrations and relative proportions of DIN species than by differences in other environmental factors.

\section{Conclusions}

Biofilm uptake responses to short-term changes in DIN concentration in the 2 Mediterranean streams investigated during the study period depended on ambient conditions, including DIN concentrations, where biofilm developed, and the DIN species considered. Under short pulses of increased DIN concentration, the stream biofilms in our study were more reactive to changes in $\mathrm{NH}_{4}{ }^{+}$than to changes in $\mathrm{NO}_{3}{ }^{-}$concentration, but ambient $U_{\mathrm{NO} 3}$ - far exceeded ambient $U_{\mathrm{NH} 4+}$, largely because $\mathrm{NO}_{3}{ }^{-}$was present at much higher concentrations. The greater kinetic response to $\mathrm{NH}_{4}{ }^{+}$may be attributable to repression of enzymes associated with $\mathrm{NO}_{3}{ }^{-}$uptake or the contribution of a different process (nitrification) to total uptake. Lack of response to $\mathrm{NO}_{3}{ }^{-}$suggests this species was present in saturating concentrations. Our results contrast with findings from laboratory-scale experiments, in which $\mathrm{NO}_{3}{ }^{-}$kinetics conformed to the Michaelis-Menten model (Eppley et al. 1969, Kemp and Dodds 2002, Maguer et al. 2011). In our study, stream biofilm communities were able to respond to increases in $\mathrm{NH}_{4}{ }^{+}$concentration, which is an energetically cheaper $\mathrm{N}$ source than $\mathrm{NO}_{3}{ }^{-}$and is the substrate for nitrification. However, we found clear differences between streams in biofilm responses to $\mathrm{NH}_{4}^{+}$that probably arose from differences in biofilm characteristics, interactions with other $\mathrm{N}$ species, such as $\mathrm{NO}_{3}{ }^{-}$, or adaptive changes in affinity.

Human activities associated with different land uses may enrich adjacent streams with DIN and alter the proportion of DIN species in the streams. Thus, streams draining catchments dominated by agricultural practices tend to be $\mathrm{NO}_{3}{ }^{-}$enriched, whereas streams draining urbanized catchments are often $\mathrm{NH}_{4}^{+}$enriched (Stanley and Maxted 2008, Lassaletta et al. 2009, Martí et al. 2010). Given widespread changes in land use, our results have implications for understanding and managing $\mathrm{N}$ losses to downstream ecosystems. The $\mathrm{N}$ species that reach stream ecosystems potentially could be retained by in-stream biofilm communities $\left(\mathrm{NH}_{4}{ }^{+}\right)$or exported downstream with the subsequent enrichment of receiving waters $\left(\mathrm{NO}_{3}{ }^{-}\right)$.

\section{Acknowledgements}

We thank A. Poch, S. Merbt, and L. Proia for excellent field assistance and J. L. Riera for assistance in statistical analyses. We are also grateful to the Font del Regàs landowners and Massaneda Garden for allowing access to the study sites during the experiments. This study was funded by the Spanish Ministry of Education and Science through the NICON project (ref: CGL2005-7362). MR was supported by a contract with the Spanish Ministry of Science and Innovation through the ISONEF project (CGL2008-05504-C02-02/BOS). MP was funded by a 
Formación de Personal Investigador PhD fellowship from the Spanish Ministry of Science and Innovation. DvS's work was also funded by a Juan de la Cierva postdoctoral contract (JCI-2010-06397) from the Spanish Ministry of Science and Innovation. NB Grimm was supported by funds from the Spanish Council for Scientific Research (CSIC).

\section{Literature Cited}

APHA (American Public Health Association). 1995. Standard methods for the examination of water and wastewater. $19^{\text {th }}$ edition. American Public Health Association, American Waterworks Association, and Water Environment Federation, Washington, DC.

Ashrenas, L. R., S. L. Johnson, S. V. Gregory, J. L. TANK, AND W. M. Wollheim. 2004. A stable isotope tracer study of nitrogen uptake and transformation in an old-growth forest stream. Ecology 85:1725-1739.

Battin, T. J., L. A. Kaplan, J. D. Newbold, and C. M. E. HANSEN. 2003. Contributions of microbial biofilms to ecosystem processes in stream mesocosms. Nature 426: 439-442.

Bernhardt, E. S., R. O. Hall, and G. E. Likens. 2002. Wholesystem estimates of nitrification and nitrate uptake in streams of the Hubbard Brook Experimental Forest. Ecosystems 5:419-430.

Bernhardt, E. S., AND G. E. LiKens. 2004. Controls on periphyton biomass in heterotrophic streams. Freshwater Biology 49:14-27.

Bernot, M. J., J. L. TANK, T. V. Royer, And M. B. DAvid. 2006. Nutrient uptake in streams draining agricultural catchments of the midwestern United States. Freshwater Biology 51:499-509.

Bothe, H., S. J. Fergusson, and W. E. Newton. 2007. Biology of the nitrogen cycle. $1^{\text {st }}$ edition. Elsevier, Oxford, UK.

Bunch, N. D., AND M. J. Bernot. 2012. Nitrate and ammonium uptake by natural stream sediment microbial communities in response to nutrient enrichment. Research in Microbiology 163:137-141.

Camargo, J. A., And A. Alonso. 2006. Ecological and toxicological effects of inorganic nitrogen pollution in aquatic ecosystems: a global assessment. Environment International 32:831-849.

Carpenter, S. R., N. F. Caraco, D. L. Correll, R. W. Howarth, A. N. Sharpley, and V. H. Smith. 1998. Nonpoint pollution of surface waters with phosphorus and nitrogen. Ecological Applications 8:559-568.

Collos, Y., A. VAquer, AND P. Souchu. 2005. Acclimation of nitrate uptake by phytoplankton to high substrate levels. Journal of Phycology 41:466-478.

Covino, T. P., B. L. McGlynn, and R. A. McNamara. 2010. Tracer additions for spiraling curve characterization (TASCC): quantifying stream nutrient uptake kinetics from ambient to saturation. Limnology and Oceanography: Methods 8:484-498.

Dodds, W. K., A. J. Lopez, W. B. Bowden, S. Gregory, N. B. Grimm, S. K. Hamilton, A. E. Hershey, E. Martí, W. H.
McDowell, J. L. Meyer, D. Morrall, P. J. Mulholland, B. J. Peterson, J. L. Tank, H. M. Valett, J. R. Webster, And W. Wollheim. 2002. $\mathrm{N}$ uptake as a function of concentration in streams. Journal of the North American Benthological Society 21:206-220.

DorTch, Q. 1990. The interaction between ammonium and nitrate uptake in phytoplankton. Marine Ecology Progress Series 61:183-201.

Earl, S. R., H. M. VAlett, and J. R. Webster. 2006. Nitrogen saturation in stream ecosystems. Ecology 87:3140-3151.

Eppley, R. W., J. N. Rogers, and J. J. McCArthy. 1969. Halfsaturation constant for uptake of nitrate and ammonium by marine phytoplankton. Limnology and Oceanography 14:912-920.

FAirchild, G. W., R. L. Lowe, AND W. B. RichardsON. 1985. Algal periphyton growth on nutrient-diffusing substrates: an in situ bioassay. Ecology 66:465-472.

Fellows, C. S., H. M. Valett, C. N. Dahm, P. J. Mulholland, AND S. A. Thomas. 2006. Coupling nutrient uptake and energy flow in headwater streams. Ecosystems 9: 788-804.

Geisseler, D., W. R. Horwath, R. G. Joergensen, and B. LUDWIG. 2010. Pathways of nitrogen utilization by soil microorganisms: a review. Soil Biology and Biochemistry 42:2058-2067.

Gieseke, A., J. L. Nielsen, R. Amann, P. H. Nielsen, and D. De BEER. 2005. In situ substrate conversion and assimilation by nitrifying bacteria in a model biofilm. Environmental Microbiology 7:1392-1404.

Gonzalez, P. J., C. Correia, I. Moura, C. D. Brondino, and J. J. G. MOURA. 2006. Bacterial nitrate reductases: molecular and biological aspects of nitrate reduction. Journal of Inorganic Biochemistry 100:1015-1023.

GRIMM, N. B., AND S. G. FisHER. 1986. Nitrogen limitation potential of Arizona streams and rivers. Journal of the Arizona-Nevada Academy of Science 21:31-43.

Hamilton, S. K., J. L. Tank, D. F. Raikow, W. M. Wollheim, B. J. Peterson, and J. R. Webster. 2001. Nitrogen uptake and transformation in a midwestern US stream: a stable isotope enrichment study. Biogeochemistry 54:297-340.

Holmes, R. M., J. W. McClelland, D. M. Sigman, B. Fry, AND B. J. Peterson. 1998. Measuring ${ }^{15} \mathrm{~N}_{-} \mathrm{NH}_{4}{ }^{+}$in marine, estuarine and fresh waters: an adaptation of the ammonia diffusion method for samples with low ammonium concentrations. Marine Chemistry 60: 235-243.

Howarth, R. W., G. Billen, D. Swaney, A. Townsend, N. Jaworski, K. Lajtha, J. A. Downing, R. Elmgren, N. Caraco, T. Jordan, F. Berendse, J. Freney, V. Kudeyarov, P. Murdoch, and Z. L. Zhu. 1996. Regional nitrogen budgets and riverine $\mathrm{N}$ and $\mathrm{P}$ fluxes for the drainages to the North Atlantic Ocean: natural and human influences. Biogeochemistry 35:75-139.

KEMP, M. J., AND W. K. DodDS. 2002. The influence of ammonium, nitrate, and dissolved oxygen concentrations on uptake, nitrification, and denitrification rates associated with prairie stream substrata. Limnology and Oceanography 47:1380-1393. 
Kim, D. J., D. I. LeE, AND J. KeLLER. 2006. Effect of temperature and free ammonia on nitrification and nitrite accumulation in landfill leachate and analysis of its nitrifying bacterial community by FISH. Bioresource Technology 97:459-468.

Koper, T. E., J. M. Stark, M. Y. Habteselassie, and J. M. NorTON. 2010. Nitrification exhibits Haldane kinetics in an agricultural soil treated with ammonium sulfate or dairy-waste compost. FEMS Microbiology Ecology 74: 316-322.

LAmBert, S. J., AND A. J. Davy. 2011. Water quality as a threat to aquatic plants: discriminating between the effects of nitrate, phosphate, boron and heavy metals on charophytes. New Phytologist 189:1051-1059.

Lassaletta, L., H. García-Gómez, B. S. Gimeno, and J. V. ROVIRA. 2009. Agriculture-induced increase in nitrate concentrations in stream waters of a large Mediterranean catchment over 25 years (1981-2005). Science of the Total Environment 407:6034-6043.

Maguer, J. F., S. L'Helguen, J. Caradec, and C. Klein. 2011. Size-dependent uptake of nitrate and ammonium as a function of light in well-mixed temperate coastal waters. Continental Shelf Research 31:1620-1631.

Martens-Habbena, W., P. M. Berube, H. Urakawa, J. R. de la TORRE, AND D. A. STAHL. 2009. Ammonia oxidation kinetics determine niche separation of nitrifying Archaea and Bacteria. Nature 461:976-979.

Martí, E., J. Riera, AND F. SABAter. 2010. Effects of wastewater treatment plants on stream nutrient dynamics under water scarcity conditions. Pages 173-195 in S. Sabater and D. Barceló (editors). Water scarcity in the Mediterranean. The handbook of environmental chemistry. Springer, Berlin, Germany.

McIntire, C. D., S. V. Gregory, A. D. Steinman, and G. A. LAMBERTI. 1996. Modeling benthic algal communities: an example from stream ecology. Academic Press, San Diego, California.

Merriam, J. L., W. H. McDowell, J. L. Tank, W. M. Wollheim, C. L. CRenshaW, AND S. L. Johnson. 2002. Characterizing nitrogen dynamics, retention and transport in a tropical rainforest stream using an in situ ${ }^{15} \mathrm{~N}$ addition. Freshwater Biology 47:143-160.

Mulholland, P. J., J. L. Tank, D. M. Sanzone, W. M. Wollheim, B. J. Peterson, J. R. Webster, and J. L. Meyer. 2000. Nitrogen cycling in a forest stream determined by a ${ }^{15} \mathrm{~N}$ tracer addition. Ecological Monographs 70: 471-493.

Mulholland, P. J., And J. R. Webster. 2010. Nutrient dynamics in streams and the role of J-NABS. Journal of the North American Benthological Society 29: 100-117.

Naldi, M., AND P. A. WheELER. 2002. ${ }^{15} \mathrm{~N}$ measurements of ammonium and nitrate uptake by Ulva fenestrata (Chlorophyta) and Gracilaria pacifica (Rhodophyta): comparison of net nutrient disappearance, release of ammonium and nitrate, and ${ }^{15} \mathrm{~N}$ accumulation in algal tissue. Journal of Phycology 38:135-144.

Newbold, J. D., T. L. Bott, L. A. Kaplan, C. L. Dow, J. K. Jackson, A. K. Aufdenkampe, L. A. Martin, D. J. van
Horn, AND A. A. DE LONG. 2006. Uptake of nutrients and organic C in streams in New York City drinking-watersupply watersheds. Journal of the North American Benthological Society 25:998-1017.

O'Brien, J. M., AND W. K. DodDs. 2008. Ammonium uptake and mineralization in prairie streams: chamber incubation and short-term nutrient addition experiments. Freshwater Biology 53:102-112.

O'Brien, J. M., AND W. K. Dodds. 2010. Saturation of $\mathrm{NO}_{3}{ }^{-}$ uptake in prairie streams as a function of acute and chronic $\mathrm{N}$ exposure. Journal of the North American Benthological Society 29:627-635.

O’Brien, J. M., W. K. Dodds, K. C. Wilson, J. N. Murdock, AND J. EICHMILLER. 2007. The saturation of N cycling in Central Plains streams: ${ }^{15} \mathrm{~N}$ experiments across a broad gradient of nitrate concentrations. Biogeochemistry 84 : 31-49.

Payn, R. A., J. R. Webster, P. J. Mulholland, H. M. Valett, AND W. K. DodDs. 2005. Estimation of stream nutrient uptake from nutrient addition experiments. Limnology and Oceanography: Methods 3:174-182.

Pusch, M., D. Fiebig, I. Brettar, H. Eisenmann, B. K. Ellis, L. A. Kaplan, M. A. Lock, M. W. Naegeli, and W. Traunspurger. 1998. The role of micro-organisms in the ecological connectivity of running waters. Freshwater Biology 40:453-495.

Redfield, A. C. 1958. The biological control of chemical factors in the environment. American Scientist 46: 205-221.

SCHANZ, F., AND H. JuON. 1983. 2 different methods of evaluating nutrient limitations of periphyton bioassays, using water from the river Rhine and 8 of its tributaries. Hydrobiologia 102:187-195.

Sigman, D. M., M. A. Altabet, R. Michener, D. C. McCorkle, B. FRY, AND R. M. Holmes. 1997. Natural abundance-level measurement of the nitrogen isotopic composition of oceanic nitrate: an adaptation of the ammonia diffusion method. Marine Chemistry 57:227-242.

SмiтH, S. L. 2011. Consistently modeling the combined effects of temperature and concentration on nitrate uptake in the ocean. Journal of Geophysical Research: Biogeosciences 116. doi:10.1029/2011JG001681

Sobota, D. J., S. L. Johnson, S. V. Gregory, And L. R. AshKenAs. 2012. A stable isotope tracer study of the influences of adjacent land use and riparian condition on fates of nitrate in streams. Ecosystems 15:1-17.

Stanley, E. H., and J. T. Maxted. 2008. Changes in the dissolved nitrogen pool across land cover gradients in Wisconsin streams. Ecological Applications 18: 1579-1590.

Sterner, R. W., J. J. Elser, And D. O. Hessen. 1992. Stoichiometric relationships among producers, consumers and nutrient cycling in pelagic ecosystems. Biogeochemistry 17:49-67.

Stewart, P. S. 2003. Diffusion in biofilms. Journal of Bacteriology 185:1485-1491.

Tank, J. L., J. L. Meyer, D. M. Sanzone, P. J. Mulholland, J. R. Webster, B. J. Peterson, W. M. Wollheim, and N. E. LEONARD. 2000. Analysis of nitrogen cycling in a forest 
stream during autumn using a ${ }^{15} \mathrm{~N}$-tracer addition. Limnology and Oceanography 45:1013-1029.

Teissier, S., M. Torre, F. Delmas, and F. Garabetian. 2007. Detailing biogeochemical $\mathrm{N}$ budgets in riverine epilithic biofilms. Journal of the North American Benthological Society 26:178-190.

Tilman, D., S. S. Kilham, and P. Kilham. 1982. Phytoplankton community ecology. The role of limiting nutrients. Annual Review of Ecology and Systematics 13:349-372.

Vadivelu, V. M., J. Keller, And Z. G. Yuan. 2007. Effect of free ammonia on the respiration and growth processes of an enriched Nitrobacter culture. Water Research 41: 826-834. von Schiller, D., E. Martí, and J. L. Riera. 2009. Nitrate retention and removal in Mediterranean streams bordered by contrasting land uses: a ${ }^{15} \mathrm{~N}$ tracer study. Biogeosciences 6:181-196.

von Schiller, D., E. Martí, J. L. Riera, and F. Sabater. 2007. Effects of nutrients and light on periphyton biomass and nitrogen uptake in Mediterranean streams with contrasting land uses. Freshwater Biology 52:891-906.

ZAR, J. H. 1996. Biostatistical analysis. $3^{\text {rd }}$ edition. PrenticeHall, Upper Saddle River, New Jersey.

Received: 17 December 2012 Accepted: 29 July 2013 